184

Received: December 11, 2013

Accepted: March 14, 2014
Macedonian Journal of Animal Science, Vol. 4, No. 1, pp. 31-35 (2014)

In print: ISSN $1857-6907$

On line: ISSN $1857-7709$

UDC: 637.354.8.054:547.56(497.775)

Original scientific paper

\title{
PRELIMINARY STUDY OF TOTAL PHENOLIC CONTENT IN TRADITIONAL SHEEP CHEESE (BIENO SIRENJE)
}

\author{
Vesna Levkov $^{1^{*}, \text { Sonja Gadžovska }}{ }^{2}$, Oliver Tuševski ${ }^{2}$, Natasha Gjorgovska ${ }^{1}$, Nataša Mateva $^{1}$ \\ 1 "Ss. Cyril and Methodius” University in Skopje, Institute of Animal Science, \\ Blvd. Ilinden 92a, 1000 Skopje, Republic of Macedonia \\ 2 "Ss. Cyril and Methodius" University in Skopje, Faculty of Natural Science and Mathematics, \\ Institute of Biology, Arhimedova 3, 1000 Skopje, Republic of Macedonia \\ levkovv@yahoo.com
}

\begin{abstract}
The presence of phenolic compounds in the milk and cheese is a result of their transfer from plant to milk and can affect their antioxidant activity. The objective of this work is to make a survey of the prevalence of the total phenolic compounds (TPC) in certain stages during cheese ripening as well as to determinate their final concentration in mature cheese. The obtained results show differences in the content of TPC between cheese samples from two batches (1 and 2). During the cheese ripening and after the dry salting and brining decreasing in the content of TPC has been noticed in both cheese batches. This is a result of number of chemical and enzymatic reactions as well as the high concentration of $\mathrm{NaCl}$ that inhibits the phenolic compounds to react with Folin reagent.
\end{abstract}

Key words: total phenolic compounds; content; sheep cheese; bieno sirenje

\section{ПРЕЛИМИНАРНИ ИСТРАЖУВАЊА НА СОДРЖИНАТА НА ВКУПНИТЕ ФЕНОЛИ ВО БИЕНО СИРЕЊЕ ПРОИЗВЕДЕНО НА ТРАДИЦИОНАЛЕН НАЧИН}

\begin{abstract}
Фенолните соединенија во млекото и сирењето се јавуваат како резултат на нивниот пренос од растенијата со кои се хранат животните во млекото и можат да влијаат врз нивната антиоксидативна активност. Целта на овие истражувања беше да се испита присуството и застапеноста на вкупните феноли (ТРC) во одредени фази од зреењето на биеното сирење, а исто така и да се одреди нивната концентрација во крајниот производ. Од добиените резултати се забележува дека постои разлика во застапеноста на вкупните феноли помеѓу двете варијанти биено сирење (варијанта 1 и 2) произведено во две различни фарми. Во текот на зреењето на сирењето, како и во фазите по суво солење и саламурење, се забележува намалување на застапеноста на вкупните феноли и кај двете испитувани варијанти. Тоа најверојатно е резултат на бројни ензимски и хемиски реакции кои се одвиваат во текот на зреењето на сирењето, но и на високата концентрација на $\mathrm{NaCl}$ која ја инхибира реакцијата помеѓу фенолните соединенија и Фолиновиот реагенс.
\end{abstract}

Клучни зборови: вкупни феноли; содржина: овчо сирење; биено сирење

\section{INTRODUCTION}

The phenolic compounds are secondary metabolites produced by variety of plants and are mostly responsible for the sensory characteristics of plant derived food and beverages, especially taste and color [1]. They belong to the group of natural antioxidants and because of their molecular structure are considered as very efficient scavengers of peroxyl radicals [2]. There is an increasing interest from consumers about phenolic compounds (as a part of healthy and functional food) because of their antioxidant, anticarcinogens and antimutagens properties [3]. The presence of phenolic compounds in the milk and later in the cheese is a result of their transfer from plant to milk. According to Hilario et al. [4] pasture plants are rich and significant source of bioactive components and they can be transferred into the milk and cheese. 
They can influence milk and cheese taste and can also affect their antioxidant activity.

The content of the total phenolic compounds is investigated at different types of cheeses like smoked cheeses [2], cheeses produced from milk in which plant extract with various concentration is added [5] and cheeses made from goat milk where animals have been subjected to different feeding systems [4].

The content of the total phenolic compounds in traditionally produced cheeses in Macedonia and the extent of their antioxidative activity have not been subject of survey yet. During the summer period pasture vegetation forms a significant part of grazing animal nutrition. Although phenolic compounds undergo modification in the animal digestive tract [6] it is interesting to investigate their presence in traditional sheep cheese (Bieno sirenje). Also it is important to consider the fact that this kind of traditional cheese is made without pasteurization [7]. It was found that pasteurization negatively influenced the total polyphenol concentration by denaturation of phenol content [4].

The objective of this work is to make a survey of the prevalence of total phenolic compounds at certain stages during cheese ripening as well as to determine their final concentration in mature cheese. The sheep cheese (Bieno sirenje) was produced traditionally without any addition of plant extract during manufacturing.

\section{MATERIAL AND METHODS}

The quantitative analyses of the total phenolic compound content were conducted on traditional cheese (Bieno sirenje) produced from raw ewe's milk. The analyzed samples were collected during three different cheese production procedures carried out in two different households during the summer period (July and August) in 2010 in Mariovo region.

The cheese production technology was similar in both households and differs only in dry ripening phase duration which on other hand is conditioned by climate and season temperatures. Raw ewe's milk from both, evening and morning milking was used to manufacture the cheese. The curdling was performed with liquid commercial rennet for 45-50 minutes without the heating of milk. The curd is thoroughly stirred with a wooden tool (3 series of 40-50 times each) and then left to settle down for 15 minutes. After that, with gentle stirring, the hot water $\left(80-90^{\circ} \mathrm{C}\right)$ was added into the vat and the curd was left to settle down for 5-10 $\min$. The curd temperature reaches $46^{\circ} \mathrm{C}$. Then the whey was removed and the curd was pressed by hand and transferred in cheesecloth. The cheesecloth was fastened and hung to drain for $24 \mathrm{~h}$ at the room temperature $\left(\sim 25^{\circ} \mathrm{C}\right)$. Next day the curd was kept for dry ripening 1-2 days (depending on ambient temperature) covered with cheesecloth in the same environment. Then the cheese was cut on rectangular slices 5-7 cm thick and salted on the surface with coarse-grained salt. Salted slices were transferred into the tins and left in the same room for 1-2 days, depending on the ambient temperature. Finally, the tins with the cheese slices are fulfilled with the brine (22\% salinity) and left to brine ripening for 45 days in the same room.

The analyzed samples were taken from investigated cheese (batch 1 and batch 2) during the dry ripening, dry salting and after 45-th day of brining. The samples were taken and transported to the laboratory in plastic containers at temperature of 4 ${ }^{\circ} \mathrm{C}$. In the laboratory the collected material was kept at low temperature $\left(-18^{\circ} \mathrm{C}\right)$ until it was analyzed.

The content of the total phenolic compounds was determined according to Gadzovska et al. [8] using grated cheese sample, $80 \%$ methanol, FolinCiocalteu reagent (1:9) and $0.7 \mathrm{M} \mathrm{Na} \mathrm{Na}_{3}$. The samples were incubated 5 minutes at $50^{\circ} \mathrm{C}$ in water bath. After cooling at room temperature the absorbance was measured by spectrophotometer at $760 \mathrm{~nm}$ wavelength. The TPC content was calculated by standard curve using the standard solution of Gallic acid $\left(0-400 \mu \mathrm{g} \cdot \mathrm{ml}^{-1}\right)$.

\section{Statistical analysis}

The results from the conducted analyses were recorded as means values, minimum and maximum values, standard deviation and coefficient of variation. The software package Statgraf 3 (Statistical Graphics, Warrenton, Virginia, USA) was used to perform $t$-test.

\section{RESULTS AND DISCUSSION}

Mariovo region is located in the south part of $\mathrm{R}$. Macedonia. It is characterized with diverse vegetation as a result of specific climate, geologic, geomorphologic and pedologic characteristics. Phytocenological analyses of highland pastures in southern part of R. Macedonia and Mariovo region have been made by Matevski and Kostadinovski [9]. According to the authors the plant association 
Biserrulo-Scleranthetum dichotomae Matevski \& Kostadinovski is composed of following characteristic species: Sclerantus perennis subsp. dichotomus, Corynephorus divaricatus, Biserrula pelecinus, Verbascum glandulosum, Galium macedonicum, Campanula scutellata, Phleum graecum and Stachys angustifolia. In the Mariovo region a few rear and interesting plant species with narrow areal of distribution have been encountered. Some of this species are: Lithrum thymifollia, Ophioglossum vulgatum, Radiola linoides, Lupinus angustifolius Matevski and Kostadinovski [10].
The phenolic compounds contained in these plants are widely distributed in plant kingdom. This kind of plant secondary metabolites can be transferred to the milk and cheese and can affected their antioxidant characteristics and taste properties [11]. Also these compounds can contribute to the cheese flavor and taste [4]. Because of that the interest for analyses of their content in the milk and milk products has been increased [1].

The content of the total phenolic compounds in traditional sheep cheese (Bieno sirenje) during different stages of ripening is shown in Table 1.

Table 1

Content of total phenolic compounds $(\mathrm{mg} / \mathrm{g})$ in different stages of cheese ripening

\begin{tabular}{lccccc|ccccc}
\hline \multirow{2}{*}{ Stage of ripening } & \multicolumn{4}{c|}{ Batch 1 } & \multicolumn{5}{c}{ Batch 2 } \\
\cline { 2 - 12 } & $\bar{x}$ & $\min$ & $\max$ & $\mathrm{Sd}$ & $\mathrm{Cv}$ & $\bar{x}$ & $\min$ & $\max$ & $\mathrm{Sd}$ & $\mathrm{Cv}$ \\
\hline Dry ripening & $0.61^{\mathrm{ac}}$ & 0.57 & 0.67 & 0.05 & 8.043 & $0.40^{\mathrm{bc}}$ & 0.38 & 0.43 & 0.03 & 6.383 \\
Dry salting & $0.47^{\mathrm{ad}}$ & 0.42 & 0.53 & 0.06 & 12.020 & $0.36^{\mathrm{bd}}$ & 0.32 & 0.38 & 0.03 & 8.311 \\
45-th day of brining & $0.55^{\mathrm{ac}}$ & 0.48 & 0.64 & 0.08 & 14.707 & $0.33^{\mathrm{bcd}}$ & 0.26 & 0.40 & 0.07 & 21.828 \\
\hline
\end{tabular}

Sd - Sdandard deviation

$\mathrm{Cv}-$ Coefficient of variation

$a, b-$ Values in the same row with no common superscript differ significantly $(p<0.05)$

$\mathrm{c}, \mathrm{d}-$ Values in the same column with no common superscript differ significantly $(\mathrm{p}<0.05)$

The obtained results shows differences in the content of total phenolic compounds between cheese samples taken from the two batches (1 and 2 ), during different stages of ripening. The increased content of total phenolic compounds in batch 1 compared to batch $2(\mathrm{p}<0.05$ in all investigated stages) may have been due to the differences in pasture plant composition, differences in animal metabolism and amino acids catabolism [2, 12]. The authors also indicate the significance of milk and cheese microorganisms activity as well as milk enzymes activity as possible features that influence the content of TPC in milk and cheese. During the process of cheese ripening and storing the concentration of TPC is decreasing probably as a result of number of chemical and enzymatic reactions witch undergoes these unstable compounds $[5,13]$. This is also noticeable in the examined cheese samples from the two batches especially after the stage of dry salting where the TPC content decreased by $23 \%$ in batch 1 and by $10 \%$ in batch 2 compared to the dry ripening stage. After the 45-th day of brining, compared to the dry ripening stage, the content of TPC is decreased by $9.84 \%$ (batch 1) and $17.5 \%$ (batch 2) in analyzed cheese samples from both households. Statistical analysis shows that content of TPC in investigated cheese samples (batch 1) within the same household differ significantly $(\mathrm{p}<0.05)$ between the stages of dry ripening and dry salting as well as dry salting and 45-th day of brining. The results of TPC content analyses from other household (batch 2) show statistically significant differences $(p<$ 0.05 ) only between cheese samples taken from dry ripening and salting stages. The process of pasteurization was not included during the manufacturing of investigated cheese (Bieno sirenje) so the decreasing of TPC content during ripening and brining was presumably a result of non standardized process of salting.

Salting of cheese is another significant feature that can influenced the content of TPC. Table 2 presents the content of $\mathrm{NaCl}$ in analyzed cheese samples from both batches. 
Table 2

Content of $\mathrm{NaCl}(\%)$ at different stages of cheese ripening

\begin{tabular}{lccccc|ccccc}
\hline \hline \multirow{2}{*}{ Stage of ripening } & \multicolumn{4}{c|}{ Batch 1 } & \multicolumn{5}{c}{ Batch 2 } \\
\cline { 2 - 11 } & $\bar{x}$ & $\min$ & $\max$ & $\mathrm{Sd}$ & $\mathrm{Cv}$ & $\bar{x}$ & $\min$ & $\max$ & $\mathrm{Sd}$ & $\mathrm{Cv}$ \\
\hline Dry salting & 3.75 & 2.43 & 4.49 & 1.14 & 30.599 & 3.76 & 3.71 & 3.79 & 0.04 & 1.159 \\
45-th day of brining & 6.07 & 5.20 & 6.51 & 0.75 & 12.453 & 6.62 & 6.52 & 6.72 & 0.10 & 1.512 \\
\hline \hline
\end{tabular}

Traditional cheese (Bieno sirenje) is characterized with high content of $\mathrm{NaCl}$ that can vary between the batches. The variation in $\mathrm{NaCl}$ concentration is a result of manual salting $(\mathrm{NaCl}$ addition in diverse quantity) as well as the diffusion rate. Salting according to Hala et al. [5] slightly decreases the content of the phenolic compounds. This is presumably caused by hiding the approach of the phenolic compounds to react with Folin reagent. On the other hand Hala et al. [13] pointed that salting induces solublization of $\mathrm{Ca}^{2+}$ and causes an increase in the surface charge, voluminosity and hydration of casein micelles. This make some of the phenolic compounds interact with water throughout hydrogen bonds and results in reduced content values of phenolic compounds.

The results shown in Table 1 are lower compared to the results of Hilario et al. [4] obtained from the analyses of raw goat milk cheese where the content of total phenolic compounds is $780 \pm 120 \mathrm{mg} / \mathrm{kg}$. The total phenolic compounds content in investigated cheese shows higher values compared to TPC in non-smoked control cheese [2].

\section{CONCLUSION}

The content of the total phenolic compounds between the two batches is different. During the cheese ripening the content of TPC is decreasing. After the dry salting and brining decreasing in the content of TPC has been noticed in both cheese batches. Such decrease is a result of number of chemical and enzymatic reactions that influence over the content of TPC in cheese as well as the high concentration of $\mathrm{NaCl}$ that inhibits the phenolic compounds to react with Folin reagent. The results of this investigation are first attempt to draw attention to the presence of certain ingredients in nutritional products, in terms of improving the food quality and its positive impact on the health of consumers. It is necessary to perform wide and detailed study regarding qualitative and quantitative characteristics of the total phenols in traditionally produced cheeses. It should be considered that the phenolic compounds participate in the creation of sensory features of food and their antioxidative activity can be modified through animal nutrition system.

\section{REFERENCES}

[1] Véronique Cheynier: Polyphenols in foods are more complex than often thought. American Journal of Clinical $\mathrm{Nu}$ trition, 81(suppl), 223S-229S (2005).

[2] Shaibanl M., Al-Mamary M., Al-Habori M.: Total antioxidant activity and total phenolic contents in Yemeni smoked cheese. Ma1aysian Journal of Nutrition, 12 (1), 87-92 (2006).

[3] Sepe L., Cornu A., Graulet B., Claps S.,Rufrano D.: Phenolic content of forage, milk, whey and cheese from goats fed Avena sativa. 10-th International Meeting on Mountain cheese, 14-15 September 2011, Dronero (cn), Italy, pp. 31-32 (2011).

[4] Hilario M. C., Puga C. D., Ocaña A. N., Gil Romo F. P.: Antioxidant activity, bioactive polyphenols in Mexican goats' milk cheeses in summer grazing. Journal of Dairy Research, 77, 20-26 (2010).

[5] Hala M. F. E., Ebtisam I. G., Sanaa M. A. B., Gad A. S., Marwa M. E. S.: Manufacture of low fat UF-soft cheese supplemented with rosemary extract (as natural antioxidant). Journal of American Science, 6 (10), 570-579 (2010).

[6] O'Connell J. E., Fox P. F.: Significance and applications of phenolic compounds in the production and quality of milk and dairy products: a review. International Dairy Journal, 11, 103-120 (2001).

[7] Levkov V., Kakurinov V.: Microbiological properties of artisanal cheese (Bieno sirenje). Journal of Hygienic Engineering and Design, 1, 325-329 (2011).

[8] Gadzovska S., Maury S., Delaunay A., Spasenoski M., Joseph C., Hagège D.: Jasmonic acid elicitation of $\mathrm{Hy}$ pericum perforatum L. cell suspensions and effects on the production of phenylpropanoids and naphtodianthrones. Plant Cell Tiss Organ Cult. 89, 1-13 (2007).

[9] Matevski V., Kostadinovski M.: Biserrulo-Scleranthetum Dichotomae Matevski et Kostadinovski ass. nova in highland pastures in Republic of Macedonia. Annual Biology 51, 25-35 (1998). 
[10] Matevski, V., Kostadinovski, M.: Contribution to flora of Macedonia, I. Annual Biology, 43-44, 191-198 (1991).

[11] Alimpić A., Oaldje M., Matevski V., Marin P. D., Duletić-Laušević S.: Antioxidant activity and total phenolic and flavonoid contents of Salvia amplexicaulis Lam. extracts. Arch. Biol. Sci., Belgrade, 66 (1), 307-316 (2014).

[12] Lopez V., Lindsay R. C.: Metabolic conjugates as precursors for characterizing flavor compounds in ruminant milks. Journal of Agricultural and Food Chemistry, 41, 446-454 (1993).

[13] Hala M. F. El-Din, Ebtisam I. Ghita, Sanaa M. A. Badran, Gad A. S., Marwa M. El-Said: Total phenolic compounds, radical scavenging and ferric reducing activity of low fat UF-soft cheese supplemented with thyme extract. Journal of Applied Science Research, 8 (4), 2335-2341 (2012). 